\title{
James Blaut's Critique of Diffusionism through a Neolithic Lens: Early Animal Domestication in the Near East
}

\author{
Christine M Rodrigue
}

Department of Geography, California State University, Long Beach, CA, USA; rodrigue@csulb.edu

\section{Introduction}

I first met Jim Blaut in 1976 when I started the graduate program at Clark University. I learned about Jim's views on diffusionism and diffusion and European exceptionalism through conversations I had with him during his visits to Clark from 1976 to 1979, during AAG meetings from 1978 to 1985 , and during a visit to his and Meca's home in Chicago in 1978. He was kind with his time, helping me with my dissertation on the origins of animal domestication in the Near East (Rodrigue 1987). He gave me a few manuscripts he thought might be helpful, one which would later be published in the Annals of the $A A G$ : "Diffusionism: A uniformitarian critique" (Blaut 1987), integrating concepts in these conversations and other articles and conference presentations.

\section{Diffusionism and Diffusion: A Uniformitarian Alternative}

Jim differentiated diffusion (the movement of an idea across space and the geography of its adoption) from diffusionism (the search for [an] original hearth[s] of concentrated inventiveness and tracing innovations across a cultural landscape of imitators). Jim defined diffusionism as a “... belief-that changes are produced by diffusion rather than (ordinarily) by independent invention and that certain places are the permanent centers of innovation" (1987:31). Diffusion is a legitimate focus of geographical analysis; diffusionism is an ideology that disparages human intellectual abilities in general and those in marginalized lands in particular. By implication, diffusionism creates a tacit blame-the-victim framework for present-day underdevelopment and marginalization, racist apologia for neocolonialism and the neoliberal prescription. 
His uniformitarian alternative describes a normative process of innovation and diffusion, to various aspects of which he refers as "cellular diffusion", "crisscross diffusion", and "ultra-rapid diffusion". Innovations sprout up randomly in a cellular region populated by interacting communities and individuals. A beneficial innovation spreads contagiously from one community to another throughout the region, even as other innovations and modifications are diffusing back. Such crisscross diffusion quickly produces change in the cultural region from one not containing a particular innovation to one in which it is fairly ubiquitous, resulting in its ultra-rapid diffusion throughout a region.

Having outlined a normal state, Jim encouraged geographers to analyze abnormal states critically. For example, in situations in which an innovation fails to make any inroads whatsoever in a region, the geographer should look for inhibiting forces, such as suppression of information by powerful interests. The diffusion of one invention often implies an anti-diffusion: the obsolescence of alternatives (eg tractors displacing draft horses), with sometimes tragic dislocations for those dependent on the older technologies. Diffusion of cultural traits, too, has often been accomplished by the displacement or extinction of populations by incoming or invading groups, resulting in what geographers politely call "sequent occupance". Jim warns about illusions that can waylay the unwary. The diffusion of one trait may be a trivial side effect dependent on and disguising another, more important, deleterious, and less obvious process. Particularly galling to Jim is phantom diffusion, an assertion that an autonomously invented local culture trait was invented elsewhere or that an imposed or forced diffusion is the voluntary local imitation of a trait invented elsewhere.

After laying out an alternative framework within which to analyze diffusion, Jim proposed five empirical tests to differentiate it from diffusionism. His first hypothesis was relevant to my dissertation project, namely, the Old World agricultural revolution may have effectively happened virtually simultaneously in large portions of Asia, Africa, and Europe, in the time between about 11,000 BP and $9000 \mathrm{BP}$, due to rapid crisscross diffusion.

\section{Premises on Domestication of the Cultural-Historical School}

Influenced, then, by Jim's ideas on how diffusionism, unilinear social development, and racism interact to reinforce one another, I began to question the premises of the quirky cultural-historical school on the question of the domestication of plants and animals. This tradition in geography traces back through Frederick and Elizabeth Simoons 
(1968), George Carter (1977), Erich Isaac (1970), Carl Johannessen (1981), and Carl Sauer (1969) to Eduard Hahn (1896) and, through him, to such influences as Johann Jakob Bachofen (1861), Friedrich Ratzel (1886), and other nineteenth century students of diffusion and social evolution. It is loosely built around the following common ideas.

\section{Well-Provisioned Sedentary Folk}

First, as Sauer argued, the early domesticators had to be well-provisioned, sedentary people in a diverse natural environment, supported by stable fishing and a storable abundance of easily obtained plant and animal foods. This reflects a belief that roving gathering-hunting peoples live on the margin of starvation, devoting most of their time to the food quest and being forced to move on frequently because of their inefficient food-collecting methods. This cultural-historical school has not yet processed the finding from ethnographic work in the 1960s that such peoples enjoy enviable amounts of leisure time, even in the most marginal habitats today (Lee and DeVore 1968). Sauer's settled folk were less likely to have the requisite leisure for domestication experiments than migratory collectors!

\section{A New Three Stages Model}

Second, Eduard Hahn questioned the then-dominant "three stages" view that human society had progressed from roving gathering-hunting through pastoral nomadism to settled agriculture, without, however, abandoning evolutionism's unilinear notion of human progress. $\mathrm{He}$ argued that pastoral nomadism presupposes settled agriculture and is a specialized derivative dependent on it. He, thus, substituted a new "three stages" scheme in some ways as rigid as the original scheme. The consequence for the cultural geographic school is a belief that the domestication of plants preceded that of animals. This argument about the prior domestication of plants then bolstered Sauer's reasoning that the original domesticators of animals already had domesticated plants and reliable sources of fish protein, so that they did not need to domesticate animals but chose to for noneconomic reasons.

\section{Religious Motivations for Animal Domestication}

Third, this cultural-historical school is anxious to debunk any economic or ecological context for the domestication of animals. Given the abundant and secure food supply, these geographers ask what could have motivated early settled horticulturalists and fishers to bother capturing and domesticating animals, especially such large and dangerous ones as cattle. Feeling they had convincingly 
eliminated economic or ecological necessity as motivation, the only sufficiently compelling motivation left for this school is religion, notably the ritualized sacrifice of animals.

\section{Primitivity, Religion, Superstition ... and Matriarchy}

Fourth, this sometimes strident emphasis on ritual and religion is rooted in a German nineteenth century social evolutionism, in which human society progressed from a primitive, religion- and superstition-permeated mindset towards the enlightened scientific rationality of Western European society in the Age of Empire. In these ruminations, the "primitive mind" was religious, superstitious, ritualized, and tradition bound.

Additionally, in a tradition going back to Johann Jakob Bachofen, early society was depicted as matrifocal, leading to matriarchal societies, whose matriarchal character exposed their primitivity. As society progressed into city states and empires, it became patriarchal, its religion centering on male deities and, in the most "advanced" religions, on a patrifocal monotheism. Influenced by this intellectual milieu, this cultural-historical tradition focussed on religion, ritual, and the Mother Goddess in the early, "primitive" societies, the societies which effected the domestication of animals.

\section{Diffusionism}

Fifth, diffusionism is a hallmark of the cultural geographic school in domestication studies. This cultural-historical school is replete with domestication hearths and diffusion routes, singular inventions and the passive adopters along the path. Methodologically, diffusion of traits is the default against which innovation would be measured: one must conclusively demonstrate that there could not have been any contact whatsoever, no matter how tenuous, between two cultures before similar traits found in both could be accepted as potentially independent innovations (Ratzel 1886:82). There is a persistent search for evidence of overland diffusion and quite some interest in pre-Columbian transatlantic and transpacific contacts.

\section{Unilinear Social Evolution, Diffusion, and Racism}

Sixth, unilinearity is common in this cultural-historical school. Human society progressed from roving gatherers-hunters through horticulture/fishing/intensive wild plant collection to seed-based agriculture and animal husbandry. The seed agriculture and herd animal based societies then produced urbanization and civilization. Any "primitive" society anywhere looked like a snapshot out of Western society's past, raising questions about why some societies were stuck on the back end of the timeline and others were on its leading edge. For this 
group of cultural geographers, such questions are approached from a belief that most humans are actually rather lazy, uninventive if given the choice. An innovation, then, is seen as a rare thunderclap of genius, especially in primitive, slowly changing societies.

The implication is that, for any given complex of innovations, there is but one or maybe a few hearths with unusual concentrations of genius, tacitly evoking racial superiority or cultural superiority. The rest of the world, mostly passive recipients of distant genial largesse, are by dint of that receptivity lesser contributors and somehow racially or culturally inferior.

\section{Results of Blaut Inspired Dissertation Research}

With an increasingly critical view of this cultural-historical school in domestication studies, I started wondering what could induce a society to elaborate religion to sacrificial extremes compared to other domestication contexts commonly cited in other disciplines (notably exchange relationships and storage of surplus food or plant resources not normally consumable by humans in animal bodies). I built a model of the social preconditions for these three contexts for animal domestication-exchange, surplus banking, and religious sacrifice-which became the centerpiece of my dissertation (Rodrigue 1987) and an article based on it (Rodrigue 1992). I tested the two models, the cultural-historical school's model and my own, against archaeological site reports from 60 sites in the Near East dating from about 20,000 years ago to about $5000 \mathrm{BP}$.

\section{Exchange: Fewest Prerequisites and Earliest Context for Domestication}

The context with the fewest preconditions is trade. Trade presupposes nothing more than slight sedentarization among roving gathererhunter bands, such that needed resources found away from a seasonal home base had to be obtained through social encounters with other, related or neighboring bands (eg shells, obsidian, flint or chert, storable plant foods or meat products). Signs of exchange appeared in Epi-Palaeolithic sites as early as 17,000 years ago and include seashells found as far as $400 \mathrm{~km}$ inland, small amounts of obsidian found as much as $400 \mathrm{~km}$ from source volcanoes, and progressively more items as time goes on.

\section{Storage: Another Very Early Context with Few Prerequisites} Localization and sedentarization, or the lengthening of stays in one spot for a season or longer, are widely evidenced in the archaeological record from areas all over the world around 14,000 to $15,000 \mathrm{BP}$. 
There is little agreement over what caused people all over the world to settle down more: the drastic environmental changes of the postWürm/Wisconsin glaciation; population growth so that human bands increasingly constrained the mobility of others; and/or the diffusion of new technologies (eg bow and arrow and microlith-studded composite tools) that made it easier to meet a group's needs in one area for a longer time by enabling it to more easily exploit a broader spectrum of resources?

By settling into and committing themselves to particular landscapes, people now experienced the full variation in environmental conditions possible at any one of these places but without the option of moving along, the time-honored way of dealing with environmental downturns. The situation demanded other responses to environmental variability: trade and mutual aid arrangements with groups in different environments and storage of surpluses collected in good times to tide people over rough patches. Storage was now meaningfully possible with sedentarization. People had places to store their "stuff", and it now made sense to expend effort on the construction of shelters, houses, and storage systems, among them animals.

Many wild animal species practically self-domesticate around human settlements, seeking food stores and spills, handouts, and salt. Animals consumed surplus food that would otherwise spoil and, by grazing or browsing in lands not directly exploitable by humans, brought those lands' biological productivity within the human dietary compass in a highly palatable form. Animals became surplus banks and storage facilities, a complement to storage pits, silos, and storage rooms, which began to manifest in Mesolithic sites about 12,000 years ago.

\section{The Downside of Sedentarization: Risk and Conflict}

For these early sedentary gathering-hunting-fishing peoples, the settled lifestyle introduced or intensified some unpleasant experiences. Among these were witnessing the full range of environmental variation possible at a single location in the variable and changing environments of the early Holocene ... and struggling to get through them with such emergency measures as broadening one's concept of acceptable foods, asking for help from groups in somewhat better circumstances, or raiding other groups. Experiencing such downturns would suggest storing food against such future disasters, focusing attention during good times on foods that are highly storable (eg cereal grains, which were migrating into the Near East about 15,000-13,000 years ago; nuts; processed acorns; and smoked and salted meat).

Another stressful new experience was the amplification of intergroup conflicts into outright wars in order to steal resources or 
expropriate territory. The atrocities committed in these incidents themselves encouraged vendettas and wars of revenge. Yet another challenging consequence was the tension growing within groups as they become more dependent on a surplus and as that surplus was increasingly centrally managed, at least in part: there is a conflict of interest between producers and managers of collective stores. The transformation of hunters into warriors no doubt led to abuses of the power of arms. Gender rôles changed with the advent of systematic warfare. Certain lineages became more influential and others more marginalized, destroying the rough egalitarianism of many roving gathering-hunting societies (Marx's "primitive communism").

\section{Religion and Ritual to Ameliorate Risk and Conflict}

I believe it is the intersection of these many unpleasant and often tragic new experiences upon sedentarization, exchange, and storage that led to the elaboration of religion. Ritual was expanded to baroque levels by peoples desperate to ease these new tensions and anxieties. Sooner or later, the killing of earmarked victims occurred to most settled societies, whether intensive fishers/hunters/gatherers or agriculturalists. Compared with the sedentarization that sets off these cascades of unintended consequences, elaborate sacrificial ritual follows, not precedes, it.

Very importantly, animals were used as sacrificial offerings only if the society needing to sacrifice them already possessed animals. If they did not already have ready access to such animals, sacrifice focused on human beings. Indeed, human sacrifice is suggested along with animal sacrifice in six of the sites in my sample, going back about 8500 years ago, quite a bit later than exchange relationships, storage, and the sedentarization that set off all three. Ritual sacrifice, then, is implausible as the context for the earliest domestications.

\section{Conclusion}

How have Jim's ideas held up in the rapidly evolving literature on the earliest domestications? Jim's first hypothesis has held up quite well in some ways and not so well in others. More species have been pushed into the $9000-11,000$ BP time frame that Jim specified. Pig and cattle domestication have been pushed back in time as far back as sheep and goats (10,000-11,000 BP for pigs [Rosenberg et al 1998] and 10,000-10,800 BP for cattle, with North Africa emerging as an early center for their domestication; (Hanotte et al 2002)). Many animal species thus appear to have been domesticated virtually simultaneously throughout the Near East and North Africa.

Also supporting Jim's first hypothesis in this region are the rather far-flung earliest signs of goat husbandry about 10,000 years ago in 
western Iran (Zeder and Hesse 2000) and barley domestication about 9500 BP in the Jordan Valley in the Levant (Badr et al 2000), while cattle may have been domesticated in northeast Africa (Hanotte et al 2002). Jim expected that independent innovations would be going on throughout a large region and then rapidly disseminated through crisscross diffusion.

Less happily for Jim's first hypothesis and more in accord with the diffusionist outlook, some of the recent DNA-based analyses of grain domestication actually do pinpoint a very particular area as the source of two domesticated wheat species, einkorn and emmer, roughly 10,000 BP: the Karacadağ Mountains and Tigris and Euphrates upland areas of southeastern Turkey and northern Syria. This is the same small area where the wild distributions of several pulses (eg chickpea, lentil, pea, and bitter vetch) overlap. This locale also produced the earliest signs of pig domestication and is not far from the area of earliest sheep domestication in northern Iraq. Quite a few domesticated species in this particular agricultural complex, thus, originated in a geographically very circumscribed area (what the cultural geographers would call a "hearth"), with diffusion outward from there, throughout the Mesolithic and Neolithic Near East and North Africa (Heun et al 1997; Lev-Yadun, Gopher and Abbo 2000; Özkan et al 2002).

So, the jury is still out on the empirical differentiation of Jim's first hypothesis and the diffusionist view he opposed with regards to the domestication of plants and animals in the broad Near East and North Africa region. His timeframe is holding up remarkably well for an increasing number of species, lending support to his idea of rapid crisscross diffusion. While his multiple-nuclei model of independent innovation seems valid for three species, it is not reflected in eight others, the domestication of which can be constrained very narrowly to a kind of small hearth.

\section{References}

Bachofen J J (1861) Das Mutterrecht: Eine Untersuchung über die Gynaikokratie der Alten Welt nach Ihrer Religiosen und Rechtlichen Natur. Stuttgart: Krais und Hoffmann

Badr A, Müller K, Schäfer-Pregl R, El Rabey H, Effgen S, Ibrahim H H, Pozzi C, Rohde W and Salamini F (2000) On the origin and domestication history of barley (Hordeum vulgare). Molecular Biology and Evolution 17:499-510

Blaut J M (1987) Diffusionism: A uniformitarian critique. Annals of the Association of American Geographers 77:30-47

Carter G F (1977) A hypothesis suggesting a single origin of agriculture. In C A Reed (ed) Origins of Agriculture (pp 89-133). The Hague: Mouton

Eriksen T H and Nielsen F S (2001) A History of Anthropology. London: Pluto Press

Hahn E (1896) Die Haustiere und Ihre Beziehungen zur Wirtschaft des Menschens. Leipzig: Duncker und Humblot

Hanotte O, Bradley D G, Ochieng J W, Verjee Y, Hill E W and Rege J E O (2002) African pastoralism: Genetic imprints of origins and migrations. Science 296:336-339 
Heun M, Schäfer-Pregl R, Klawan D, Castagna R, Accerbi M, Borghi B and Salamini F (1997) Site of einkorn wheat domestication identified by DNA fingerprinting. Science 278:1312-1314

Isaac E (1970) Geography of Domestication. Englewood Cliffs, NJ: Prentice-Hall

Johannessen C L (1981) Folk medicine uses of melanotic Asiatic chickens as evidence of early diffusion to the New World. Social Science and Medicine 15:427-434

Lee R B and DeVore I (eds) (1968) Man the Hunter. Chicago, IL: Aldine

Lev-Yadun S, Gopher A and Abbo S (2000) The cradle of agriculture. Science 288:1602-1603

Özkan H, Brandolini A, Schäfer-Pregl R and Salamini F (2002) AFLP analysis of a collection of tetraploid wheats indicates the origin of emmer and hard wheat domestication in Southeast Turkey. Molecular Biology and Evolution 19:1797-1801

Ratzel F (1886) The History of Mankind, vol I. Translated by A J Butler from Völkerkunde (2nd ed). New York: MacMillan

Rodrigue C M (1987) "An evaluation of ritual sacrifice as an explanation for early animal domestications in the Near East.” Unpublished PhD dissertation, Clark University

Rodrigue C M (1992) Can religion account for early animal domestications? A critical assessment of the cultural geographic argument, based on Near Eastern archaeological data. The Professional Geographer 44:417-430

Rosenberg M, Nesbitt R, Redding R W and Peasnall B (1998) Hallan Çemi, pig husbandry, and post-Pleistocene adaptations along the Taurus-Zagros Arc (Turkey). Paléorient 24:25-41

Sauer C O (1969) Seeds, Spades, Hearths, and Herds. Cambridge, MA: MIT Press

Simoons F J and Simoons E (1968) A Ceremonial Ox of India. Madison, WI: University of Wisconsin Press

Zeder M A and Hesse B (2000) The initial domestication of goats (Capra hircus) in the Zagros Mountains 10,000 years ago. Science 287:2254-2257 